ГОСПОДАРСЬКЕ ПРАВО, ГОСПОДАРСЬКО-ПРОЦЕСУАЛЬНЕ ПРАВО

УДК $346.7 ; 656.614 .3$

DOI https://doi.org/10.32844/2618-1258.2019.3-1.1

АЯГУТ Н.Г.

\title{
ПРОБЛЕМИ ПРАВОВОГО РЕГУЛЮВАННЯ ТРАНСШИПМЕНТУ ЯК ОСОБЛИВОГО РЕЖИМУ НАДАННЯ ПОРТОВИХ ПОСЛУГ
}

У статті виявлено правову основу застосування режиму трансшипменту в українському законодавстві. Здійснено аналіз нормативно-правових джерел з регулювання трансшипменту і встановлено, що визначення трансшипменту на законодавчому рівні відсутнє, і це призводить до проблем його застосування і розвитку в Україні. Запропоновано розглядати трансшипмент як певний режим, що включає кілька етапів: підготовчий, основний і кінцевий. Розшифровано зміст цих етапів. Зазначено, що залежно від кінцевого пункту призначення вантажів, що обробляються в режимі трансшипменту, цей режим поділяється на зовнішній і внутрішній. 3'ясовано, що режим трансшипменту має як переваги, так і недоліки. До переваг віднесено: збільшення вантажопотоків та оновлення портової інфраструктури. Що ж до недоліків, то вони концентруються здебільшого навколо якості надання послуг з перевезень та економічних ризиків для перевізників. Встановлено, що за рівнем розвитку трансшипменту можна класифікувати морські порти. Зокрема, порти, в яких здійснюється перевалка контейнерних вантажів в режимі трансшипменту, можна назвати транзитними портами-хабами. Також розглянуто питання щодо застосування режиму трансшипменту у вітчизняній портовій галузі в історичному аспекті та на сучасному етапі. Визначено місце цього режиму в українських морських портах та виведено основні причини низького рівня розвитку трансшипменту в Україні. Запропоновано способи розвитку цього режиму. Зазначено характерні особливості застосування режиму трансшипменту в Україні та відмічено, що з огляду на стан вітчизняної транспортної галузі акцентувати увагу необхідно на розвитку внутрішнього трансшипменту, з метою налагодження вектору взаємодії «річка - море». Охарактеризовано трансшипмент як особливий режим надання портових послуг з навантажувально-розвантажувальних робіт. Виявлено основні проблеми правового регулювання трансшипменту в Україні та зазначено, що для їх вирішення необхідний комплексний підхід. 3 метою вирішення проблем правового регулювання сформульоване поняття трансшипменту для подальшого застосування.

Ключові слова: транзит вантажів, коносамент, перевалка контейнерів, транспортний вузол, порт-хаб.

The article reveals the legal basis for the application of the transshipment regime in Ukrainian legislation. An analysis of regulatory sources for transshipment regulation has been carried out and it is established that there is no definition of transshipment at the legislative level, which leads to problems of its application and development in Ukraine. It is suggested to consider transshipment as a specific mode, comprising several stages: preparatory, basic and final. The contents of these stages are deciphered. It is noted that, depending on the final destination of the cargo processed in transshipment mode, this mode is divided into external and internal. It is noted that the transshipment mode has both advantages and disadvantages. The advantages include increased freight traffic and upgrading of the port infrastructure, and noted that the shortcomings mainly focus on

(C) АЯГУТ Н.Г. - ад’юнкт кафедри господарсько-правових дисциплін (Донецький юридичний інститут Міністерства внутрішніх справ України) 
the quality of the provision of transport services and the existence of economic risks for carriers. It is established that according to the level of transshipment development it is possible to classify seaports, and it is stated that seaports in which transshipment of container cargo is carried out can be called transit ports hubs. The place of this regime in the Ukrainian seaports is determined and the main reasons for the low level of development of transshipment in Ukraine are outlined. Ways to develop this regime are suggested. The peculiarities of the application of the transshipment regime in Ukraine are noted, and it is noted that, given the state of the domestic transport industry, attention should be paid to the development of the internal transshipment in order to adjust the river-sea interaction vector. Transshipment is characterized as a special mode of port services for loading and unloading works. The main problems of legal regulation of transshipment in Ukraine have been identified and a comprehensive approach is needed to solve them. As a first step to solving the problems of legal regulation the concept of transshipment is formulated for further use.

Key words: transit of goods, bill of lading, transshipment of containers, transport hub, port hub.

Вступ. Розвиток морських портів напряму залежить від обсягів вантажопотоків, збільшення яких своєю чергою збільшує дохід портових підприємств. Для залучення вантажопотоків українські морські порти повинні мати конкурентоспроможні порівняно з іноземними портами умови в сфері надання портових послуг. Така потреба з'явилась і щодо необхідності застосування режиму трансшипменту у вітчизняних морських портах близько 10 років тому, коли румунський морський порт Констанца, обробляючи близько 50\% вантажів в режимі трансшипменту, став пунктом вимушеної зупинки для перевалки вантажних контейнерів перед прибуттям в українські порти, оскільки на той час в Україні режим трансшипменту не застосовувався [1]. 3 огляду на це були прийняті зміни до Закону України «Про транзит вантажів», які запроваджували режим спрощеного митного оформлення вантажів за формулою «море - море» в українських портах, але прямого комплексного підходу, що регулював би саме режим трансшипменту, українське законодавство не містить. Серед наукової літератури $є$ невелика кількість публікацій з дослідження проблем трансшипменту, які досліджували О.П. Подцерковний, Д.Ю. Сіюшов, В.В. Щербина та інші вчені.

Постановка завдання. Метою статті є розкриття змісту трансшипменту як особливого режиму здійснення операцій з навантажувально-розвантажувальних робіт у морських портах 3 огляду на його застосування в українській портовій галузі на рівні сталих правил та законодавчого закріплення.

Результати дослідження. Поняття трансшипменту в українському законодавстві відсутнє, але спроби законодавчого визначення цього режиму були. Так, проект Закону України «Про особливості здійснення обробки та оформлення вантажів в контейнерах, контейнерів та транспортних засобів, що їх перевозять» містив наступне поняття трасшипменту: «транзит товарів, що переміщуються морським і річковим транспортом у контейнерах, під час зберігання залишаються в межах одного пункту пропуску чи зони митного контролю морського, річкового порту» [2]. Але за результатами опрацювання вищевказаного проекту Держмитслужбою було прийнято рішення про недоцільність його прийняття. Однією із причин було тлумачення поняття трансшипменту, яке, на думку спеціалістів Держмитслужби, поглинається визначенням транзиту, наведеним у ст. 90 Митного Кодексу, а саме: «транзит - це митний режим, відповідно до якого товари та/або транспортні засоби комерційного призначення переміщуються під митним контролем між двома митними органами України або в межах зони діяльності одного митного органу без будь-якого використання цих товарів, без сплати митних платежів та без застосування заходів нетарифного регулювання зовнішньоекономічної діяльності» [3].

Слід зазначити, що на думку О.П. Подцерковного і Д.Ю. Сіюшова прийняття Закону України «Про особливості здійснення обробки та оформлення вантажів в контейнерах, контейнерів та транспортних засобів, що їх перевозять» дозволило би вирішити деякі проблеми, пов'язані $з$ процесом обробки контейнерів у режимі трансшипменту у морських портах і зробити цей процес більш якісним, швидким й економічним. Водночас поняття трансшипменту, надане в проекті вищевказаного закону, не повною мірою відображало суті трансшипменту, «адже з економічної точки зору трансшипмент передбачає не просто транзит товарів у контейнерах, а й перевантаження контейнерів $з$ одного судна на інше» [4, с. 483]. 
Як зазначалось у самому проекті Закону України «Про особливості здійснення обробки та оформлення вантажів в контейнерах, контейнерів та транспортних засобів, що їх перевозять», метою його прийняття було «збільшення обсягів вантажів, що переміщуються у контейнерах через порти України, підвищення ефективності використання інфраструктури портів шляхом законодавчого визначення особливостей здійснення обробки та оформлення вантажів, що переміщуються у контейнерах, контейнерів і транспортних засобів, що їх перевозять» [2].

Натомість вищевказаний закон не було прийнято, тому трансшипмент регулюється нормами Закону України «Про транзит вантажів». Так, в ч. 6 ст. 6 вказаного Закону зазначається, що «на товари (крім підакцизних), що переміщуються транзитом морським і річковим транспортом у контейнерах та під час зберігання, залишаються в межах одного пункту пропуску чи зони митного контролю морського порту, вантажна митна декларація не подається» [5].

Але слід підкреслити, що не визначивши поняття трансшипменту ні в окремому законі, ні в Законі України «Про транзит вантажів», законодавці тим самим залишили процес трансшипменту, що застосовується у морських портах України, без чіткого визначення та, відповідно, без належного регулювання. Враховуючи, що перевалка вантажів в режимі трансшипменту все ж застосовується в морських портах в Україні, це вимагає встановлення суті, місця і ролі цього режиму в сфері надання портових послуг.

«Трансшипмент» - слово іншомовного походження, що у перекладі з англійської (анг. Transshipment) означає «перевалка», по суті, трансшипмент - це перевалка контейнерних вантажів. При цьому трансшипмент треба розглядати не просто як спосіб перевалки контейнерів, а як певний процес, що включає кілька етапів (рис. 1).

Підготовчий етап, який включає створення необхідних умов для здійснення трансшипменту в порту прибуття

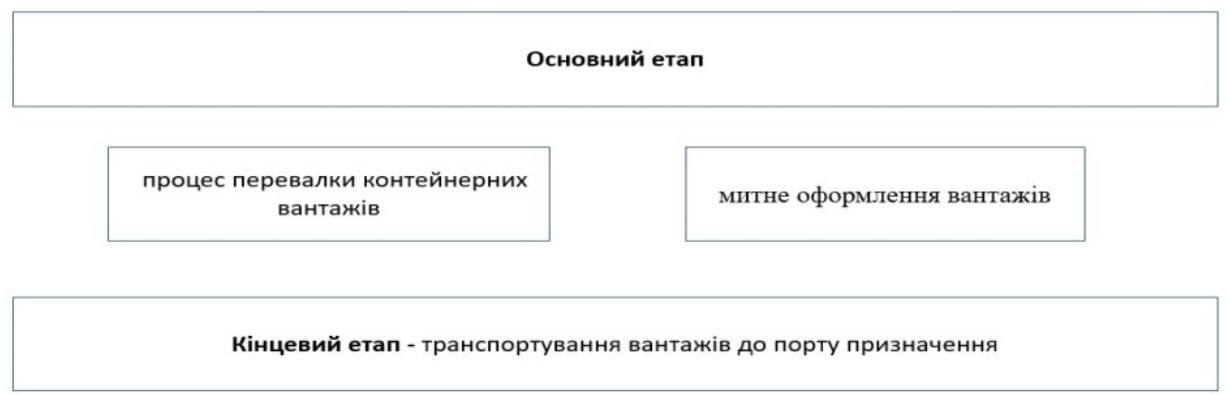

Pис. 1

Таким чином, трансшипмент можна визначати і як спрощену схему митного оформлення вантажів, і як умову коносаменту를, я як перевалку контейнерів.

Вищевказаний кінцевий етап трансшипменту передбачає транспортування вивантажних контейнерів з одного великотоннажного судна на інші - фідерні судна та їх спрямування до пункту призначення: іншого морського чи річкового порту в межах країни чи в іноземний порт. Залежно від пункту призначення трансшипмент поділяється на внутрішній і зовнішній.

Щодо одного із пунктів вказаного основного етапу трансшипменту - «митного оформлення вантажів», то слід зазначити, що основна вимога повноцінного впровадження трансшипменту у діяльність портів з боку законодавців полягала саме в спрощенні митних формальностей. Як зазначалось в пояснювальній записці до проекту Закону України «Про внесення змін до Закону України «Про транзит вантажів», основною метою законопроекту є: «спрощення процедури

1 Транспортний документ, який виконує три функції: доказ поставки товару на борт судна, свідчення договору перевезення, засіб передачі прав на товар у дорозі іншій стороні шляхом передачі їй документу (відповідно до офіційних правил тлумачення торговельних термінів Міжнародної торгової палати IНКОТЕРМС) 
оформлення контейнерів у транзитному сполученні, що прибувають і відвантажуються водним транспортом» [1]. Однак вирішуючи питання про те, до якої сфери відносин - господарських чи митних - більшою мірою належать правовідносини, що виникають з трансшипменту, то слід розглядати митне оформлення вантажу з точки зору супровідного процесу здійснення господарської діяльності з перевалки вантажів.

Отже, класичний трансшипмент як процес, що складається з кількох етапів, полягає у тому, що судно заходить у порт прибуття і не покидаючи зону митного контролю чи зону пропуску, яким є територія цього порту, перевантажується на більш маленькі фідерні судна, які і здійснюють подальше транспортування контейнерних вантажів до порту призначення. Схематично це представлено на рис. 2.

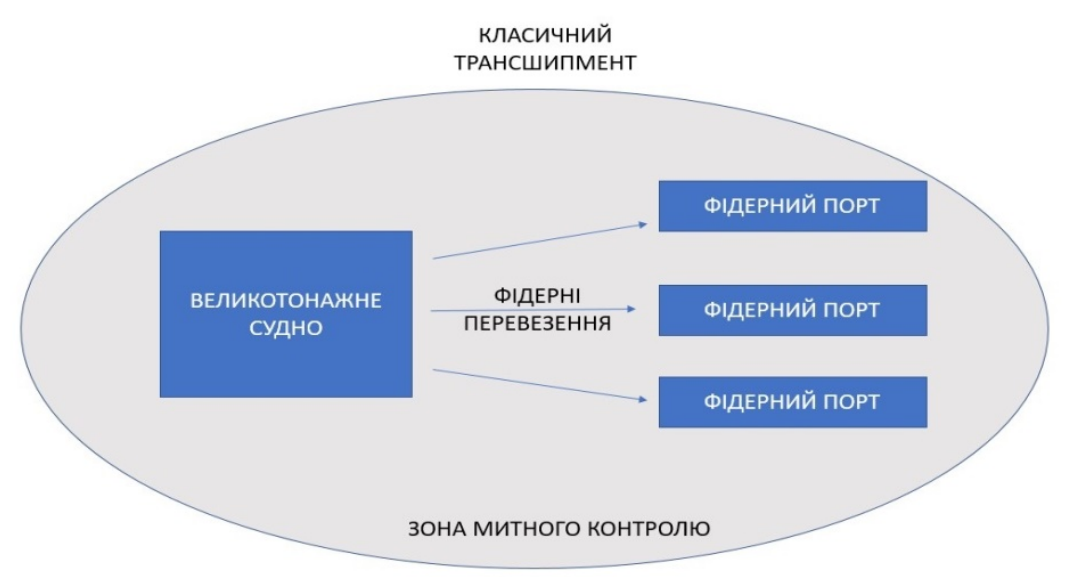

Рис. 2. Схема класичного трансшипменту.

Серед цілей трансшипменту є не тільки розвиток транзиту, а й цілісний розвиток морського порту. Оскільки цей режим забезпечує збільшення вантажопотоків шляхом зменшення часу обробки вантажів та економічних затрат на митне оформлення, то введення режиму трансшипменту сприяє розвитку порту, в якому він застосовується, шляхом залучення вигідними умовами до користування послугами саме цього порту. Однак трансшимпент як режим 3 надання певних видів портових послуг має як переваги, так і недоліки, що відображаються на продуктивності того чи іншого морського порту, в якому він застосовується.

До переваг трансшипменту можна віднести:

1. Збільшення вантажопотоків шляхом:

- оптимізації логістичних операцій, яка полягає у тому, що великі судна слідують магістральними шляхами між портами і немає необхідності витрачати час та кошти для заходу цих суден у кожен порт, що знижує собівартість перевезень;

- застосування спеціальних правил митного оформлення, яке зменшує вартість послуги 3 перевалки вантажів та часу обробки вантажів.

2. Оновлення портової інфраструктури. Застосування режиму трансшипменту потребує створення специфічних технічних, технологічних, кадрових та інформаційних умов у морському порту, що, з одного боку, сприяє оновленню портової інфраструктури і розвитку порту загалом, а з іншого - потребує значних інвестицій.

До недоліків трансшипменту належать:

1. Наявність принципу взаємозалежності учасників трансшипменту, який має такі прояви:

- взаємозалежність великотоннажного флоту від фідерного флоту. Так, невідповідність кількості великих контейнеровозів та фідерних судів може призвести до ризику дефіциту;

- взаємозалежність лінійних перевізників від фідерних перевізників;

2. Наявність ризиків для лінійних перевізників. Лінійні перевізники залежать від ринку послуг, через мінливий характер якого вони схильні до впливу економічно невигідних для них ситуацій. Так, останнім часом відмічається тенденція до посилення уваги щодо сегменту фідер- 
них перевезень. Великі компанії, що здійснюють свою діяльність у морських портах, переорієнтовуються не на кількісний, а на якісний склад вантажів, обираючи той, що користується попитом.

Морські порти, які здійснюють обробку вантажів в режимі трансшипменту, також називаються портами-хабами (транспортними вузлами). Поняття «порт-хаб» виникло завдяки розробці моделі «хаб-ендспок» (рисунок 3), яка виглядає як принцип «маточини i спиці» і першочергово застосовувалась у авіаційній галузі.

Втім, хабом можна назвати не тільки морський порт, що пристосований для перевалки контейнерних вантажів в режимі трансшипменту, а й інші утворення, принцип дії яких побудований на моделі «хаб-ендспок». Якщо говорити порт-хаб як порт, в якому застосовується режим трансшипменту, то більш підходяща для нього назва - транзитний порт-хаб.

У своїй роботі В.В. Щербіна наводить поділ портів саме за рівнем трансшипменту на фідерні порти або порти-шлюзи, регіональні порти-шлюзи, хаби-порти і чисті хаби-порти, де рівень вантажопотоку, переробленого в режимі трансшипменту, складає 90\% від

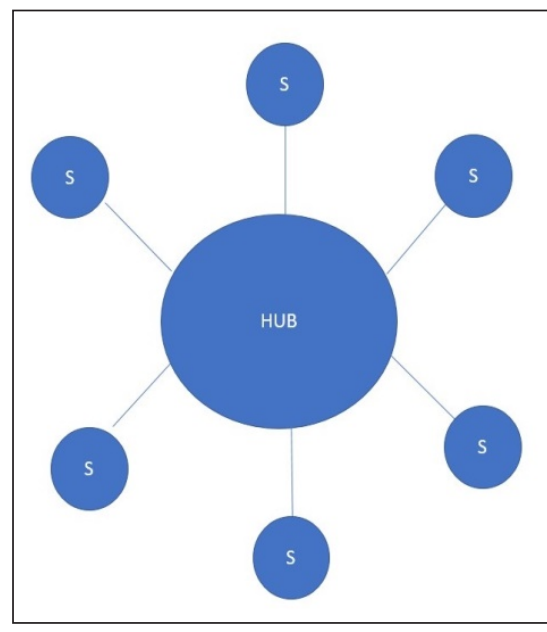

Рис. 3. Модель «хаб-енд-спок» (анг. Hub\&Spoke) загального [6, с. 95-97].

На території України функціонують 13 морських портів. Всі вони мають ряд відмінностей, включаючи різне географічне розташування і технічні можливості. Як зазначалось в пояснювальній записці до проекту Закону України «Про внесення змін до Закону України «Про транзит вантажів», найбільш придатними до залучення транзитних контейнерів у режимі «трансшипмента» є українські порти: Іллічівський (зараз морський торговельний порт «Чорноморськ») та Одеський, а можливості порту Чорноморськ «по всіх основних експлуатаційних критеріях можна порівняти з можливостями порту Констанца²» [1].

Вперше в історії вітчизняних портів перевалку вантажів в режимі трансшипменту у 2011 році здійснив Одеський морський порт та його партнер ТОВ «Бруклін-Київ порт» [7]. Однак в Україні, на жаль, трансшипмент не отримав належного розвитку, і українські порти можна віднести до «фідерних» портів, де частка вантажопотоку, обробленого в режимі трансшипменту, складає менше $10 \%$.

Можливо причинами цього $є$, по-перше, той факт, що процес введення у вітчизняну портову галузь режиму трансшипменту тривав три роки, що призвело до його несвоєчасності; по-друге, наявний підхід законодавців до визначення процесу перевалки контейнерних вантажів в режимі трансшипменту не відповідає дійсності. Відповідно до цього підходу трансшипмент ототожнюється 3 транзитом і це призводить до нівелювання таких етапів трансшипменту, як створення необхідних умов для його здійснення і розвитку. Зміна цього підходу на інший, заснований на впровадженні елементів трансшипменту у вітчизняних морських портах, саме з огляду на його системність як особливого режиму надання портових послуг, допоміг би вирішити питання зменшення вантажопотоків, від якого останнім часом потерпає портова галузь в Україні.

Враховуючи особливості транспортного комплексу України на сучасному етапі його розвитку, більшої уваги потребує розробка та вдосконалення порядку здійснення внутрішнього трансшипменту, який стане способом покращення взаємодії морський-річковий транспорт. Зараз переважна частка оброблених у морських портах вантажів доставляється по Україні автомобільним транспортом, враховуючи навантаження на дороги та екологію, вбачається необхідність налагодження вантажних перевезень від морських портів-хабів річковими шляхами до місця призначення і навпаки.

Розвиток внутрішнього і зовнішнього трансшипменту в Україні потребує:

- оновлення портової інфраструктури морських і річкових портів України та приведення iii у відповідність до ефективного здійснення внутрішнього та зовнішнього трансшипменту; іншими

2 Румунський порт, в якому частка по обробці вантажів в режимі трансшипменту превалює над 
- покращення послуг з фідерних перевезень і контроль за їх наданням;

- вдосконалення законодавства по регулюванню трансшипменту, яке дозволило б реалізувати проекти внутрішнього та зовнішнього трансшипменту в Україні.

Вирішення проблем правового регулювання трансшипменту в Україні потребує комплексного підходу і першим кроком у цьому напрямі стане надання поняття трансшипменту для закріплення на рівні законодавства.

Висновки. Таким чином, українське законодавство з регулювання режиму трансшипменту складається в основному із Закону України «Про транзит вантажів», в якому містяться окремі положення щодо порядку митного оформлення перевалки вантажів у контейнерах, але не надано визначення трансшипменту як режиму. Це призводить до однобічності у розумінні трансшипменту і тягне за собою низький рівень розвитку цього режиму в Україні. Тому пропонується на законодавчому рівні визначити трансшипмент як особливий режим надання портових послуг, який здійснюється у порту за наявності певних умов і полягає у перевантаженні вантажів у контейнерах з одного судна на інше на території порту з метою транспортування вантажів до місия призначення, використовуючи певний порядок документального оформлення. При цьому, визначивши трансшипмент особливим режимом, акцентуємо увагу на його багатогранності, а не тільки на спеціальних умовах митного оформлення.

\section{Список використаних джерел:}

1.До проекту Закону України «Про внесення змін до Закону України «Про транзит вантажів». Пояснювальна записка. URL: w1.c1.rada.gov.ua > pls > zweb2 > webproc34 (дата звернення: 01.10.2019).

2.Про проект Закону України «Про особливості здійснення обробки та оформлення вантажів в контейнерах, контейнерів та транспортних засобів, що їх перевозять»: лист Міністерства доходів і зборів України від 21.05.2014. URL: https://zakon.rada.gov.ua > rada > show (дата звернення: 01.10 .2019$)$

3.Митний Кодекс України від 09.11.2012. № 4495-VI. URL: https://zakon.rada.gov.ua > (дата звернення: 03.10.2019).

4.Підцерковний О.П., Сіюшов Д.Ю. Законодавчі проблеми трансшипменту в контексті розвитку морських портів України. Актуальні проблеми держави і права: зб. наук. праџь. 2013. № 69. С. 483-489.

5.Про транзит вантажів. Закон України від 24.12.1999. № 1172-XIV. URL: https://zakon. rada.gov.ua > ... (дата звернення: 04.10.2019)

6.Щербіна В.В. Розвиток трансшипменту як режиму перевалки контейнерних вантажів. Розвиток методів управління та господарювання на транспорті. 2016. № 1(54). С. 89-100.

7.Одесский порт первым на украинском рынке переваливал трансшипмент. URL: www. port.odessa.ua > press-tsentr > novosti > port > 18019-odeskij-port-p... (дата звернення: 03.10.2019) 